\title{
The Path to Excellence. Celebrating the 100 Years of the Romanian National Opera House Cluj-Napoca. The Hive for Beeing an Opera Singer
}

\author{
Liliana BIZINECHE ${ }^{1}$
}

\begin{abstract}
This article has two main goals. The first is to give a personal point of view regarding excellence through singing, referring the experience of the author as an opera singer, who sung in the opera company of Cluj Opera House at the 80's. It will be done a special reference to another artist of excellence, the mezzo soprano Lya Pop, who was a founder member of the first Romanian Opera House, the Cluj Opera House. The second goal is to honor this institution, the Romanian National Opera House Cluj-Napoca, that celebrates in 2020 its first century of existence.
\end{abstract}

Key-words: opera singer, opera theater, Cluj-Napoca

\section{Introduction}

Is inspiration worthy of praise? That is the air you breathe and transforms itself into sound! The feeling that makes you sing your voice, lays in the depths of your being. It is there where the source of the bearer's instrument, that arouses certain envy with the instrumentalists, lays. The courage to exploit this gift depends on anyone. The talent and work power overlap, complete each other, the baggage is gradually enriched and remains yours. My goal is to explain my point of view regarding excellence through singing, using my own experience as a singer, and Lya Pop's testimony, as an example of an artist of excellence and a founder member of the first Romanian Opera House, the Cluj Opera House, that was also my first hive where I grew as a singer. I would like to honor this institution too, that celebrates nowadays its first century of existence.

\footnotetext{
${ }^{1} \mathrm{PhD}$, Évora University Music Department, lilianabizineche@uevora.pt
} 


\section{Opera singer - A Profession hard to fathom}

What inspires you?

It is never about how good your voice is; it is only about feeling the urge to sing, and then having the courage to do it with the voice you are given

It is hard work to become an opera singer, hours and hours of training and search to build an instrument that evolves constantly. Despite the innate gift and talent, one cannot be a professional opera singer without discipline. The comparison with the top performing athlete is ideal, the objectives are as follows (Sandage and Hoch 2018, 419):

1. Continuous improvement with a constant search;

2. Maintaining the physical and energetic body, the support of the mental balance in order to transform the sound of the instrument and to recreate the composer's score.

The need to present through sensitivity and musical intelligence is the quintessence of the work. Quite intangible, withdrawn due to the care and consciousness of the instrument, the singer needs special conditions such as rest, peace of mind, contemplation, and reflection.

The comparison with the miner's hard job is often used because its high energy consumption. During an opera evening if one sings a principal role, especially in Wagner operas, one may lose more than one kilo.

On the other hand, the opera singer's profession is also by its very nature, hard to understand, seen weird from afar, even by the musicians, but it comes up with that aura within appreciated as being a Diva's. The singer is a rara avis for the talent he/she possesses.

The introversion comes from the care and consciousness of maintaining the important state of health and fitness of the vocal instrument which is in perfect communion with the body and soul. The externalization of emotions occurs when the artist can detach himself/herself from the score, having control over the vocal technique, without losing its spotlight. He/she wears the character's clothes going through its feelings and situations with passion creating thus its life and death. It is essential that the instrument's technique has the ability to render the complexity of the feelings. Repetitio mater studiorum est ${ }^{2}$ - Practice is vital in building up one's confidence.

\footnotetext{
${ }^{2}$ Repetition is the mother of the study.
} 
The Path to Excellence. Celebrating the 100 years of the Romanian National Opera House 29

\section{The Hive for beeing an opera singer}

The stage is itself a school of one's profession, aiming to train young artists by respecting the rules proposed and imposed by experienced professionals.

Looking for a way to illustrate the laborious world of the opera productions and the role of those who work there, the hive metaphor occurred to me, where the working bees subsequently transform in a joint effort the pollen into an elixir, which is nothing else but the opera production. Opera as a genre is the most complex form of artistic interpretation and theatre remains the temple of art.

The overall integration as a whole is being done gradually with the help of the prep pianist, the conductor and the stage director. Successful productions remain those in which the music and the stage are at the same level of brilliance. It needs time, knowhow, energy, and patience to put together soloists, choir, orchestra, stage, lights, and scenarios all in balance for a high quality. Each one is doing its best part for a supreme purpose, maintains the youthfulness of the genre and the passion of the audience. The Cluj Opera House, an example of this common work, like a hive, has taught generations of artists through a close and permanent collaboration work of the invisible army of dedicated people.

\section{The Romanian National Opera House Cluj-Napoca at 100 years old (1920-2020)}

This year's festivities celebrating one hundred years old since the foundation of the National Romanian Opera in Cluj failed to shed light on the event because of the pandemic situation. An opportunity for pride and exaltation, the inception of the first national opera in the heart of Transylvania was the moment when the Romanian musicians with high patriotic ideals founded institutions that became a cultural symbol of those times (the National Opera of Bucharest was only founded one year after). One of these musicians is Tiberiu Brediceanu, who was born in Lugoj into a family of intellectuals involved in everything related to Romanian culture and language. After the Union in 1918, while he was leading the Diligent Council of Sibiu, he organized cultural institutions and had the merit to set up the foundations of the Conservatory of Music and Dramatic Art in 1919 in the town on the banks of River Someș (Florea 2004, 36).

The stage director Constantin Pavel starts the project in view of setting up an opera and operetta troupe that forms the nucleus of the Romanian Opera House in Cluj. Simultaneously and in the same building, was founded the National Theatre, that was led by the writer Zaharia Stancu. The performances would be presented alternatively the same way they are today (Florea 2004, 36). 
The opening of the first season on 25 May 1920 in Cluj was laborious, because for the staging of the opera Aida by G. Verdi, a professional machine was needed, where in fact many ingredients were missing. With instrumentalists from Vienna and the choir formed by the students of the Conservatory, Constantin Pavel as a tenor and stage director managed the performance thanks to the guest soprano Elena Roman, mezzo soprano Lya Pop, among others singers, and conductor Alfred Novak. Later after the premiere, Dimitrie Popovici Bayreuth, a famous Wagnerian singer from București is invited as a Director of the Opera House. Because of his experience and knowledge in choosing the repertoire, the institution improved the quality of the performances and the public success. George Georgescu and young Jean Bobescu were invited to conduct the orchestra and by this time the institution had 14 soloists, 57 choristers and 70 instrumentalists (Florea 2004, 37).

After the success with the opera Aida other masterpieces were directed and the artistic evolution of young Cluj Opera House becomes famous all over the country. The special value of those personalities of culture who had a vision and a great trust in the Romanian talent potential is to be appreciated and always reminded to the future generations.

\section{Mezzo soprano Lya Pop Popovici: singer and teacher}

In this hive, many people were important, they worked to improve and to raise to the complex art of the Opera to the highest levels, but the soloist singer stands out. I would like to honor the first mezzo soprano singer of this Opera House, who was also a founding member, who lived searching the path of excellence. Lya Pop had a brilliant career as a singer and a singing teacher for three decades in Cluj. Though she had obtained a contract in 1918 at the Vienna Opera House, she decided to return home to Romania. Her debut at the inaugural show on 25 May 1920 with the role of Amneris in the opera Aida by G. Verdi started her way to success. Lya Pop sung the major opera roles as Dalila, Carmen, Azucena, Orfeo, Hérodiade, Suzuki, Ulrika, who brought her on stage for more than 700 productions. She was also known for her recitals with Romanian composers so appreciated live or on radio programs as from the press critics. Her stage interpretations during the tours of the Cluj Opera House within Romania's important cities as Oradea, Arad, Timișoara, Cernăuți, Sibiu, Brașov and București, left unforgettable feelings to the public (Vătăşan-Hăngănuţ 1974, 93).

Her ability to represent diametrically opposed styles and characters sung with a vocal force doubled by a special technique and expressiveness brought her success. The approach of mezzo soprano and contralto scores with the same perfectionism and ease was the result of permanent and profound work and a real awareness of her artistic responsibility (Vătăşan-Hăngănuţ 1974, 96). 
She shone in opera performances with partners, that belong to the same artistic hives, among so many others Aca de Barbu (soprano), Constantin Pavel (tenor), Constantin Ujeicu (bass), Elena Roman (soprano), Lya Hubic (soprano) and Traian Grozăvescu (tenor) in Cluj, and in București Opera House with George Folescu (bass), Jean Athanasiu (tenor) and Petre Ștefănescu Goangă (bass baritone). The generations of lyrical artists who are today just names in the hall programs and posters of the time were much loved and admired (Vătăşan-Hăngănuţ 1974, 96).

Lucia Vătăşan collected some of the critics from the culture reviews that stated the following: "a rare quality with an unusual vocal extension, homogeneity in transmission and an efficient technique" (Vătăşan-Hăngănuţ 1974, 95) and the "expressiveness of her interpretation to which is added the fiery stage temperament as well as the sincerity and ease in creating the characters, where the qualities that ensured, along with her persevering work and the awareness of artistic responsibility, the evolution of her lyrical career”’3 (Vătăşan-Hăngănuţ 1974, 96).

She was invited by the composer Gheorghe Dima, who was the chancellor of Cluj Music Conservatory, to lead the singing class in 1921. She taught valuable students during her 28 years at the department. Her memoirs about the teaching pedagogy of singing are very interesting. She used to organize the study, dedicating 3 hours per week for each student. For the first years of study she used the same technical exercises employed by Garcia, Concone, Panofka, Luetgen, Vaccaj, romantic lied and opera arias (Vătăşan-Hăngănuţ 1974, 97).

Her idea was to educate the observation of the sound together with the feeling of proper pitch and musicality. The future singer must be respected because his instrument is very sensitive, and the choice of the repertoire was approached with care according to the personal capacity of understanding and response. After acquiring the appropriate vocal technique through systematic and repeated exercises, the student managed to render through the expressiveness of the pronunciation and the musical phrase the content of the poem. The importance of studying the French, English, German languages is part of the curriculum of future artists (Vătăşan-Hăngănuţ 1974, 98).

Lya Pop's words prove the seriousness she attaches to the interpretative act, on the interview given to Mircea Vaida in 1969:

"The essential condition in the secret of creation is the external and internal echo of the voice, meaning the soul, the idea, the world as it is conceived by the composer, poet or librettist, gone through the performer's understanding. In opera, the music must be spoken, the text must be respected, both the melodic phrase and the content of the words. I consider very important,

\footnotetext{
${ }^{3}$ Translated from Romanian by Marinescu Crăiţa.
} 
during the development of any singer the subtle and deep knowledge of the Lied interpretation. A phrase or a high note in an aria can be camouflaged by the orchestra; but in Lied recital you are vulnerable, naked, there are no possibilities of deceiving. In Lied, it is when one understands the quality of the voice, the range, the beauty, the musicality of the interpretation and especially the sensitivity and the intelligence of the singer". ${ }^{4}$ (VătăşanHăngănuţ 1974, 98-99)

Her students have successfully followed into the master's footsteps, some of them being part of a constellation of great opera names inside and outside Romania.

\section{Beeing part of the hive $e^{5}$.}

Liliana Bizineche, a mezzo soprano with a sumptuous and warm timbre Pierre Petit, musical critic of Le Figaro

Looking back at my first years of opera I nostalgically appreciate the joy, seriousness, and enthusiasm of preparing a role with all its difficulties in the context of the Cluj ensemble, where I started as company soloist in 1980 . The daily rehearsals with the pianists, the conductor and the orchestra followed by an intense stage work, made possible a premiere during those two months of work. This is how I performed the mezzo soprano roles in the new productions of Carmen, Così fan Tutte, Le Nozze di Figaro, Boris Godunov, Nabuccodonosor, Rigoletto, Madama Butterfly, II Barbiere di Seviglia and many others were staged. We were a privileged generation because we had a whole institution, the Theatre that organized an operatic production down to the smallest detail. We had great maestros like Petre Sbârcea, Cristian Mandeal, Tiberiu Popovici, the director Viorel Gomboșiu and valuable scenographers working with us. An art institution has a particularly important function, namely, to educate and elevate generations of spectators-students who enjoyed the music of the great composers. These opera enthusiasts grew up with the names of sopranos Ana Rosza Vasilescu, Lucia Stănescu, Angela Nemeș, Elena Andrieș, tenor Emil Gherman and baritones Dan Serbac, Vasile Catana, among many other devoted and great artists. The youngsters who spent the evenings at the Opera were being left with indelible memories, the subtle force of the music, enriching everyone's universe profusely.

\footnotetext{
${ }^{4}$ Translated from Romanian by Marinescu Crăiţa.

${ }^{5}$ To know more about the author: (Bizineche, 2012a), (Bizineche, 2012b), (Bizineche, 2012c).
} 
However, a gap between generations was real and disturbed the life in the hive - often the experienced soloists criticized the new productions with the young singers. I was one of those who felt it deeply as a beginner artist.

I left the country in 1986 saying goodbye to my parents and maestros from the Opera that trained me and where I had experienced so many artistic satisfactions with colleagues and friends. I was part of an artistic family and that improved my skills very much.

I needed to change my career for family reasons; I was not a member of the Opera House anymore and started a career as a freelancer in an unknown world. The recipe continued to be perseverance and confidence in my own talent. But, in another way, it was certain that I have found the freedom to make music and to travel at a time when this was not possible in my country.

Settled down in Lisboa, Portugal, I could continue the career as a soloist, recording CDs and performed at the famous theatres in the world like Royal Albert Hall (London), Teatro Collon (Buenos Aires), Theatre de Champs Elysee (Paris), Theatre de La Monnaie (Bruxelles), Auditorio Nacional (Madrid), Palau de la Musica (Barcelona), Musikverein (Wien), the Royal Concertgebouw (Amsterdam), Teatro São Carlos (Lisboa) and many other well-known concerts halls. As an opera and concert soloist, I was privileged to sing under the direction of many conductors, like Lord Yehudi Menuhin, Carlo Rizzi, Antonio Pappano, Zubin Mehta, Kurt Masur, George Prêtre, Gerd Albrecht, Lawrence Foster, Rudolf Barshai, M. Rostropovich and to share the stage with well-known artists like: Alfredo Kraus, José Carreras, Ileana Cotrubas, Nicolae Herlea, Teresa Berganza, Nicolai Gedda, José van Damm, Feruccio Furlanetto, Gundula Janovitz, Barbara Frittoli, Inga Borg, among others.

Talking about being a professional freelancer (based on a 30 years' experience) I think that such a career was built on a physical and mental structure well rooted in my own intelligence and intuition. In fact, the essence of the profession is a solitary one. Myself, I managed to share my doubts and fears with teachers or with my colleagues. My point of view is that the closest relationship of a singer is with his teacher, it is the one who knows very well and cares about the vocal treasure. I would like to pay my respect to my beloved Maestra, the soprano Valentina Creţoiu, who was there for me over thirty years in good and bad times (the relationship was so strong that a single phone call from her was sufficient to boost my confidence).

I dedicated my life to teaching students at the Music Department of Évora University alongside my performing career as a freelance soloist. My students already have brilliant singing careers. It was a revelation for me to read Lya Pop's testimonies, as I recognize the same values and principles of sharing knowledge, in the pedagogy and preparation of young singers. In fact, it is an unbreakable lineage in the path to excellence. 


\section{Conclusions}

Through all those testimonies I wanted to emphasize the important role of Music Conservatory and Opera House as being essential for the beginning and the continuation of a singer's life. Nevertheless, the singer's trail to high performance continues to go on and on whether one belongs to an opera company or not, because discipline, dedication and reverence would be the way for the path to excellence to come true.

\section{Acknowledgements}

I am very grateful to my friend Crăiţa Marinescu from "Liceul Unirea" Brașov for the English translation and for the great ideas about my article.

I cannot be less grateful for the intense and passionate work that Maria João Sousa, my dear friend, ex-student with a beautiful soprano voice has done to publish this article.

\section{References}

Popa, Costin. 2012b. "Liliana Bizineche în dialog cu Costin Popa (II): Cântecul popular românesc în Portugalia (Cultura sunetelor)." [Liliana Bizineche in dialogue with Costin Popa (II): The Romanian folk song in Portugal (Culture of sounds)]. Revista Cultura. Bucureşti, 393: 26-27. https://revistacultura. ro/nou/2012/10/cantecul-popular-romanesc-in-portugalia-ii/

Popa, Costin. 2012c. Cultura cântărețului este primordială - interviu cu mezzosoprana Liliana Bizineche. Cronica Muzicală On-Line [The singer's culture is paramount - interview with mezzo-soprano Liliana Bizineche. OnLine Music Chronicle]. Retrieved from http://www.cimec.ro/Muzica/Cronici/CostinPopa237.html

Florea, Anca. 2004. Ecuaţia Brediceanu [Brediceanu Equation]. Bucureşti: Editura Muzicală.

Sandage, Mary J. and Matthew Hoch. 2018. "Exercise Physiology: Perspective for Vocal Training." Journal of Singing 74(4): 419-425. Retrieved from https://www.nats.org/_Library/JOS_On_Point/JOS-074-4-2018-419__Exercise_Physiology_-_Sandage-Hoch.pdf

Vătăşan-Hăngănuţ, Lucia. 1974. Mezzo-soprana Lya Pop-Popovici - Cintăreaţă şi profesoară [Mezzo-soprano Lya Pop-Popovici - Singer and teacher]. București: Lucrări de Muzicologie 10: 91-99. 